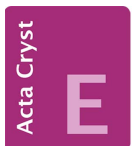

CRYSTALLOGRAPHIC COMMUNICATIONS

ISSN 2056-9890

\section{Crystal structures of deuterated sodium molybdate dihydrate and sodium tungstate dihydrate from time-of-flight neutron powder diffraction}

Received 1 June 2015

Accepted 10 June 2015

Edited by M. Weil, Vienna University of Technology, Austria

Keywords: neutron powder diffraction; sodium molybdate dihydrate; sodium tungstate dihydrate

CCDC references: 1406122; 1406121 Supporting information: this article has supporting information at journals.iucr.org/e

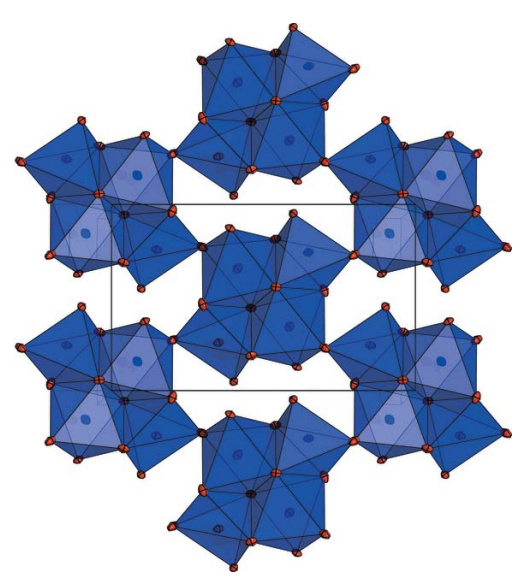

OPEN $\odot$ ACCESS

\section{A. Dominic Fortes}

ISIS Facility, Rutherford Appleton Laboratory, Harwell Science and Innovation Campus, Didcot, Oxfordshire OX11 0QX, England, Department of Earth Sciences, University College London, Gower Street, London WC1E 6BT, England, and Department of Earth and Planetary Sciences, Birkbeck, University of London, Malet Street, London WC1E 7HX, England. *Correspondence e-mail: andrew.fortes@ucl.ac.uk

Time-of-flight neutron powder diffraction data have been measured from $\sim 90 \mathrm{~mol} \%$ deuterated isotopologues of $\mathrm{Na}_{2} \mathrm{MoO}_{4} \cdot 2 \mathrm{H}_{2} \mathrm{O}$ and $\mathrm{Na}_{2} \mathrm{WO}_{4} \cdot 2 \mathrm{H}_{2} \mathrm{O}$ at $295 \mathrm{~K}$ to a resolution of $\sin (\theta) / \lambda=0.77 \AA^{-1}$. The use of neutrons has allowed refinement of structural parameters with a precision that varies by a factor of two from the heaviest to the lightest atoms; this contrasts with the $\mathrm{X}$-ray based refinements where precision may be $>20 \times$ poorer for $\mathrm{O}$ atoms in the presence of atoms such as Mo and $\mathrm{W}$. The accuracy and precision of interatomic distances and angles are in excellent agreement with recent X-ray single-crystal structure refinements whilst also completing our view of the hydrogen-bond geometry to the same degree of statistical certainty. The two structures are isotypic, spacegroup $\mathrm{Pbca}$, with all atoms occupying general positions, being comprised of edge- and corner-sharing $\mathrm{NaO}_{5}$ and $\mathrm{NaO}_{6}$ polyhedra that form layers parallel with (010) interleaved with planes of $X \mathrm{O}_{4}(X=\mathrm{Mo}, \mathrm{W})$ tetrahedra that are linked by chains of water molecules along [100] and [001]. The complete structure is identical with the previously described molybdate [Capitelli et al. (2006). Asian J. Chem. 18, 2856-2860] but shows that the purported threecentred interaction involving one of the water molecules in the tungstate [Farrugia (2007). Acta Cryst. E63, i142] is in fact an ordinary two-centred 'linear' hydrogen bond.

\section{Chemical context}

$\mathrm{Na}_{2} \mathrm{MoO}_{4}$ and $\mathrm{Na}_{2} \mathrm{WO}_{4}$ are unusual amongst the alkali metal mono-molybdates and mono-tungstates in being highly soluble in water and forming polyhydrated crystals. Additionally, sodium apparently plays a significant role in the solvation of other alkali metal ions to form a range of double molybdate and tungstate hydrates (Klevtsova et al., 1990; Klevtsov et al., 1997; Mirzoev et al., 2010), for example, $\mathrm{Na}_{3} \mathrm{~K}\left(\mathrm{MoO}_{4}\right)_{2} \cdot 9 \mathrm{H}_{2} \mathrm{O}$. Both dihydrate and decahydrate varieties of the two title compounds are known, their solubilities as a function of temperature being well characterised (Funk, 1900; Zhilova et al., 2008). The structures of the decahydrates have not yet been reported, although I have established that they are not isotypic with the sodium sulfate analogue, $\mathrm{Na}_{2} \mathrm{SO}_{4} \cdot 10 \mathrm{H}_{2} \mathrm{O}$, as had hitherto been thought.

The dihydrates have been the subject of extensive crystallographic studies, from descriptions of their density, habit and measurements of interfacial angles (Svanberg \& Struve, 1848; Zenker, 1853; Rammelsberg, 1855; Marignac, 1863; Delafontaine, 1865; Ullik, 1867; Clarke, 1877; Zambonini, 1923), through to determination of absolute unit-cell parameters (Pistorius \& Sharp, 1961), and subsequent solution and 
Table 1

Comparison of the $X-\mathrm{O}(X=\mathrm{Mo}, \mathrm{W})$ and $\mathrm{Na}-\mathrm{O}$ bond lengths $(\AA)$ in $\mathrm{Na}_{2} \mathrm{MoO}_{4} \cdot 2 \mathrm{D}_{2} \mathrm{O}$ and $\mathrm{Na}_{2} \mathrm{WO}_{4} \cdot 2 \mathrm{D}_{2} \mathrm{O}$ with those of the protonated isotopologues reported in the literature.

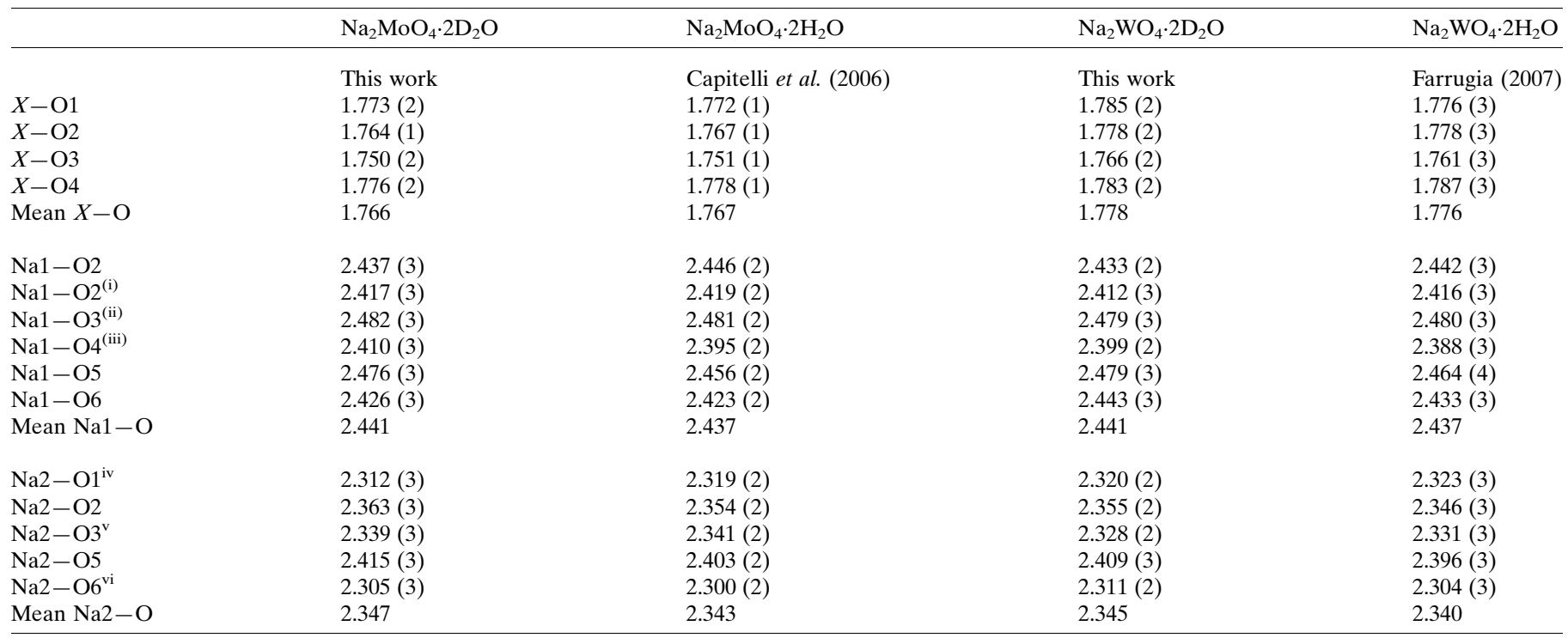

Symmetry codes: (i) $1-x, 1-y, 1-z$; (ii) $-\frac{1}{2}+x$, $\frac{3}{2}-y, 1-z$; (iii) $\frac{1}{2}-x,-\frac{1}{2}+y, z$; (iv) $\frac{1}{2}+x, \frac{3}{2}-y, 1-z$; (v) $\frac{3}{2}-x,-\frac{1}{2}+y, z$; (vi) $\frac{1}{2}+x, y$, $\frac{3}{2}-z$.

refinement of their structures (Mitra \& Verma, 1969; Okada et al., 1974; Matsumoto et al., 1975; Atovmyan \& D'yachenko, 1969; Capitelli et al., 2006; Farrugia, 2007). However, the presence of heavy atoms in these materials makes it impossible to achieve a uniform precision on all structural parameters using X-rays, and even with single-crystal methods that purport to identify hydrogen positions there may be significant inaccuracies. Such problems are minimised using a neutron

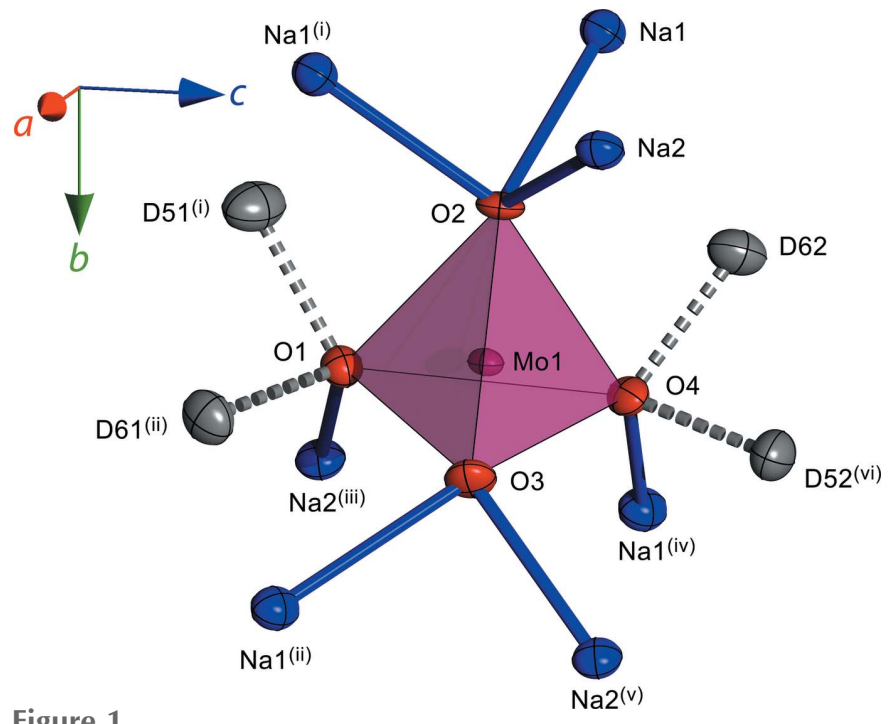

Figure 1

First and second coordination shell of $\mathrm{Mo}^{6+} / \mathrm{W}^{6+}$ in the title compounds, revealing differences in the environment of each apical $\mathrm{O}^{2-}$ that are responsible for the variations in $\mathrm{Mo}-\mathrm{O}$ and $\mathrm{W}-\mathrm{O}$ bond lengths. Anisotropic displacement ellipsoids are drawn at the $50 \%$ probability level. [Symmetry codes: (i) $1-x, 1-y, 1-z$; (ii) $\frac{1}{2}+x, \frac{3}{2}-y, 1-z$; (iii) $-\frac{1}{2}+x, \frac{3}{2}-y, 1-z ;$ (iv) $\frac{1}{2}-x, \frac{1}{2}+y, z ;(\mathrm{v}) \frac{3}{2}-x, \frac{1}{2}+y, z ;$ (vi) $1-x, \frac{1}{2}+y$, $1.5-z$. radiation probe since the coherent neutron scattering lengths of the constituent elements differ by less than a factor of two, being $6.715 \mathrm{fm}$ for Mo, $4.86 \mathrm{fm}$ for $\mathrm{W}, 3.63 \mathrm{fm}$ for $\mathrm{Na}, 5.803 \mathrm{fm}$ for O, and $6.67 \mathrm{fm}$ for ${ }^{2} \mathrm{D}$ (Sears, 1992). Thus one can locate accurately all of the light atoms and obtain a uniform level of precision on their coordinates and displacement parameters. Since the incoherent neutron scattering cross section of ${ }^{1} \mathrm{H}$ is large ( 80.3 barns) it is usual to prepare perdeuterated specimens whenever possible (the incoherent cross section of ${ }^{2} \mathrm{D}$ being only 2.1 barns) as this optimises the coherent Bragg scattering signal above the background, reducing the counting times required for a high-precision structure refinement from many days to a matter of hours on the instrument used for these measurements. These data were therefore measured using $\mathrm{Na}_{2} \mathrm{MoO}_{4} \cdot 2 \mathrm{D}_{2} \mathrm{O}$ and $\mathrm{Na}_{2} \mathrm{WO}_{4} \cdot 2 \mathrm{D}_{2} \mathrm{O}$ samples.

The occurrence of polyhydrated forms of both $\mathrm{Na}_{2} \mathrm{MoO}_{4}$ and $\mathrm{Na}_{2} \mathrm{WO}_{4}$ suggests that both would be excellent candidates for the formation of hydrogen-bonded complexes with watersoluble organics, such as amino acids, producing metal-organic crystals with potentially useful optical properties $(c f$., glycine lithium molybdate; Fleck et al., 2006). High-pressure polymorphs of $\mathrm{Na}_{2} \mathrm{MoO}_{4} \cdot 2 \mathrm{H}_{2} \mathrm{O}$ and $\mathrm{Na}_{2} \mathrm{WO}_{4} \cdot 2 \mathrm{H}_{2} \mathrm{O}$ are indicated from Raman scattering studies (Luz-Lima et al., 2010; Saraiva et al., 2013). Characterising the structures and properties of the title compounds provides an essential foundation on which to build future studies of the high-pressure phases, of the asyet incomplete decahydrate structures and any related organic-bearing hydrates.

\section{Structural commentary}

$\mathrm{Na}_{2} \mathrm{MoO}_{4} \cdot 2 \mathrm{H}_{2} \mathrm{O}$ and $\mathrm{Na}_{2} \mathrm{WO}_{4} \cdot 2 \mathrm{H}_{2} \mathrm{O}$ are isotypic, crystallizing in the orthorhombic space group $\mathrm{Pbca}$; all atoms occupy 
Table 2

Comparison of the water molecule and hydrogen bond geometry $\left(\AA,{ }^{\circ}\right)$ in $\mathrm{Na}_{2} \mathrm{MoO}_{4} \cdot 2 \mathrm{D}_{2} \mathrm{O}$ and $\mathrm{Na}_{2} \mathrm{WO}_{4} \cdot 2 \mathrm{D}_{2} \mathrm{O}$ with the protonated isotopologues as

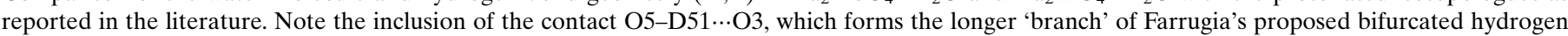
bond.

\begin{tabular}{|c|c|c|c|c|}
\hline & $\mathrm{Na}_{2} \mathrm{MoO}_{4} \cdot 2 \mathrm{D}_{2} \mathrm{O}$ & $\mathrm{Na}_{2} \mathrm{MoO}_{4} \cdot 2 \mathrm{H}_{2} \mathrm{O}$ & $\mathrm{Na}_{2} \mathrm{WO}_{4} \cdot 2 \mathrm{D}_{2} \mathrm{O}$ & $\mathrm{Na}_{2} \mathrm{WO}_{4} \cdot 2 \mathrm{H}_{2} \mathrm{O}$ \\
\hline & This work & Capitelli et al. (2006) & This work & Farrugia (2007) \\
\hline O5-D51 & $0.977(2)$ & 0.68 & $0.970(2)$ & $0.86(3)$ \\
\hline O5-D52 & $0.966(2)$ & $0.76(3)$ & $0.959(2)$ & $0.86(3)$ \\
\hline $\mathrm{D} 51 \cdots \mathrm{O} 1^{(\mathrm{i})}$ & $1.874(2)$ & $2.16(3)$ & $1.873(2)$ & 2.09 (4) \\
\hline $\mathrm{O} 5-\mathrm{D} 51 \cdots \mathrm{O} 1^{(\mathrm{i})}$ & $167.9(2)$ & 167 (4) & $168.2(2)$ & $145(6)$ \\
\hline $\mathrm{D} 51 \cdots \mathrm{O} 3^{(\mathrm{ii})}$ & - & - & - & $2.70(6)$ \\
\hline $\mathrm{O} 5-\mathrm{D} 51 \cdots \mathrm{O} 3^{(\mathrm{ii})}$ & - & - & - & $122(5)$ \\
\hline O6-D61 & $0.972(2)$ & $0.83(3)$ & $0.968(2)$ & $0.86(3)$ \\
\hline O6-D62 & $0.972(2)$ & $0.71(3)$ & $0.966(2)$ & $0.86(3)$ \\
\hline D61-O6-D62 & $103.0(2)$ & $105(3)$ & $103.2(2)$ & $95(5)$ \\
\hline $\mathrm{D} 61 \cdots \mathrm{O} 1$ & $1.816(2)$ & $2.01(3)$ & $1.834(2)$ & $1.95(3)$ \\
\hline $\mathrm{O} 6-\mathrm{D} 61 \cdots \mathrm{O} 1$ & $167.0(2)$ & $167(3)$ & $167.0(2)$ & $167(6)$ \\
\hline $\mathrm{D} 62 \cdots \mathrm{O} 4^{(\mathrm{iii})}$ & $1.868(4)$ & $2.08(3)$ & $1.876(2)$ & $2.02(4)$ \\
\hline
\end{tabular}

Symmetry codes: (i) $1-x, 1-y, 1-z$; (ii) $1-x,-\frac{1}{2}+y, \frac{3}{2}-z$; (iii) $-\frac{1}{2}+x, \frac{3}{2}-y, 1-z$.

general positions (Wyckoff sites $8 c$ ). Note that the atom labelling scheme and space-group setting used here follows Farrugia (2007); consequently there are some differences with respect to other literature sources, although equivalent contacts are referred to in Table 1 and Table 2. The $X^{6+}$ ions $(X=\mathrm{Mo}, \mathrm{W})$ are tetrahedrally coordinated by $\mathrm{O}^{2-}$, the Mo$\mathrm{O}$ and $\mathrm{W}-\mathrm{O}$ bond lengths varying slightly according to the type of coordination adopted by a particular apex: O1 and O4 are each coordinated to $\mathrm{Na}^{+}$and each also accepts two hydrogen bonds; $\mathrm{O} 2$ is coordinated to three $\mathrm{Na}^{+}$ions and $\mathrm{O} 3$ is coordinated to two $\mathrm{Na}^{+}$ions (Fig. 1). In both title compounds, $X-\mathrm{O} 1$ and $X-\mathrm{O} 4$ are the longest contacts and $X-\mathrm{O} 3$ is the shortest contact in the tetrahedral oxyanion. The mean Mo$\mathrm{O}$ and $\mathrm{W}-\mathrm{O}$ bond lengths are in good agreement with those found in the anhydrous crystals (Fortes, 2015). Furthermore, each of the absolute $\mathrm{Mo}-\mathrm{O}$ bond lengths are identical (within
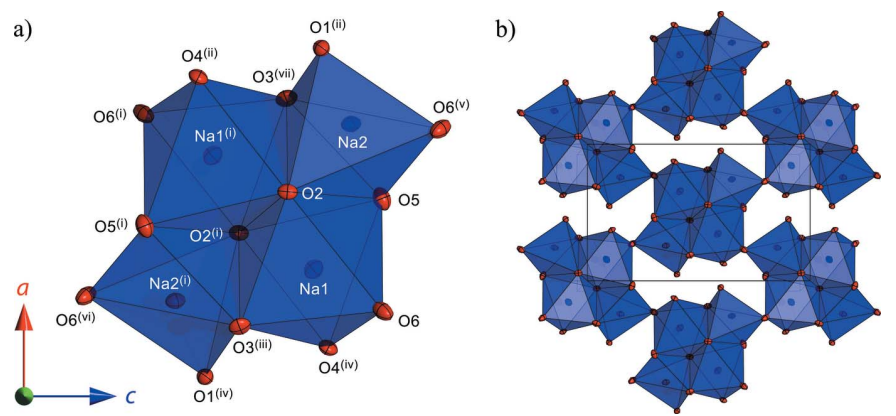

Figure 2

(a) Arrangement of $\mathrm{NaO}_{x}$ polyhedra into edge-sharing clusters comprised of two $\mathrm{Na}_{1} \mathrm{O}_{6}$ octahedra and two $\mathrm{Na}_{2} \mathrm{O}_{5}$ square pyramids; (b) Arrangement of the clusters shown in $(a)$ by corner sharing to form 'slabs' parallel (010). Ellipsoids are drawn at the $50 \%$ probability level. [Symmetry codes: (i) $1-x, 1-y, 1-z$; (ii) $\frac{1}{2}+x, \frac{3}{2}-y, 1-z$; (iii) $-\frac{1}{2}+x$, $\frac{3}{2}-y, 1-z$; (iv) $\frac{1}{2}-x,-\frac{1}{2}+y, z$; (v) $\frac{1}{2}+x, y, \frac{3}{2}-z$; (vi) $\frac{1}{2}-x, 1-y, \frac{1}{2}+z$; (vii) $\frac{3}{2}-x,-\frac{1}{2}+y, z$.] error) to those found by Capitelli et al. (2006); the agreement in $\mathrm{W}-\mathrm{O}$ bond lengths with Farrugia (2007) is marginally poorer.

The $\mathrm{Na}^{+}$ions occupy two inequivalent sites: in one, $\mathrm{Na}^{+}$is six-fold coordinated by two water molecules and four $\mathrm{XO}_{4}{ }^{2-}$ oxygen atoms, yielding an octahedral arrangement; in the second, $\mathrm{Na}^{+}$is five-fold coordinated by two water molecules and three $\mathrm{XO}_{4}{ }^{2-}$ oxygen atoms, yielding a square-pyramidal arrangement. These two polyhedra share a common edge (O2-O5) and are connected, moreover, with their inversioncentre-related neighbours along three other shared edges to form a cluster (Fig. 2a). The clusters corner-share via O6 to create a 'slab' parallel to (010) (Fig. 2b). The mean $\mathrm{Na}-\mathrm{O}$ bond lengths are statistically identical in $\mathrm{Na}_{2} \mathrm{MoO}_{4} \cdot 2 \mathrm{D}_{2} \mathrm{O}$ and $\mathrm{Na}_{2} \mathrm{WO}_{4} \cdot 2 \mathrm{D}_{2} \mathrm{O}$ being $\sim 1.6 \%$ longer in the $\mathrm{NaO}_{6}$ octahedra and $\sim 2.3 \%$ shorter in the $\mathrm{NaO}_{5}$ polyhedra than $\mathrm{Na}-\mathrm{O}$ bonds in the anhydrous crystals (Fortes, 2015). The agreement in $\mathrm{Na}-\mathrm{O}$ bond lengths with the X-ray single crystal studies of Capitelli et al. (2006) and Farrugia (2007) is very good. Overall, the agreement in bond lengths and angles for the two independently refined data sets is excellent (Tables 1 and 2).

Although it is more usual to find $\mathrm{Na}^{+}$in octahedral coordination, there are abundant examples of $\mathrm{Na}^{+}$in five-fold coordination, including instances where the $\mathrm{NaO}_{5}$ polyhedron adopts a square-pyramidal arrangement (Beurskens \& Jeffrey, 1961; Císařová; et al., 2001; Sharma et al., 2005; Smith \& Wermuth, 2014; Aksenov et al., 2014) or the alternative trigonal-bipyramidal arrangement (Mereiter, 2013; Smith, 2013). A similar combination of $\mathrm{NaO}_{6}$ and $\mathrm{NaO}_{5}$ polyhedra to that found in the title compounds occurs in the closely-related hydrates $\mathrm{Na}_{2} \mathrm{CrO}_{4} \cdot 1.5 \mathrm{H}_{2} \mathrm{O}$ and $\mathrm{Na}_{2} \mathrm{SeO}_{4} \cdot 1.5 \mathrm{H}_{2} \mathrm{O}$ (Kahlenberg, 2012; Weil \& Bonneau, 2014). The two water molecules form hydrogen-bonded chains between the $\mathrm{O} 1$ and $\mathrm{O} 4$ atoms of the tetrahedral oxyanions; O5-related chains extend along [001] and O6-related chains crosslink them in a staggered fashion 

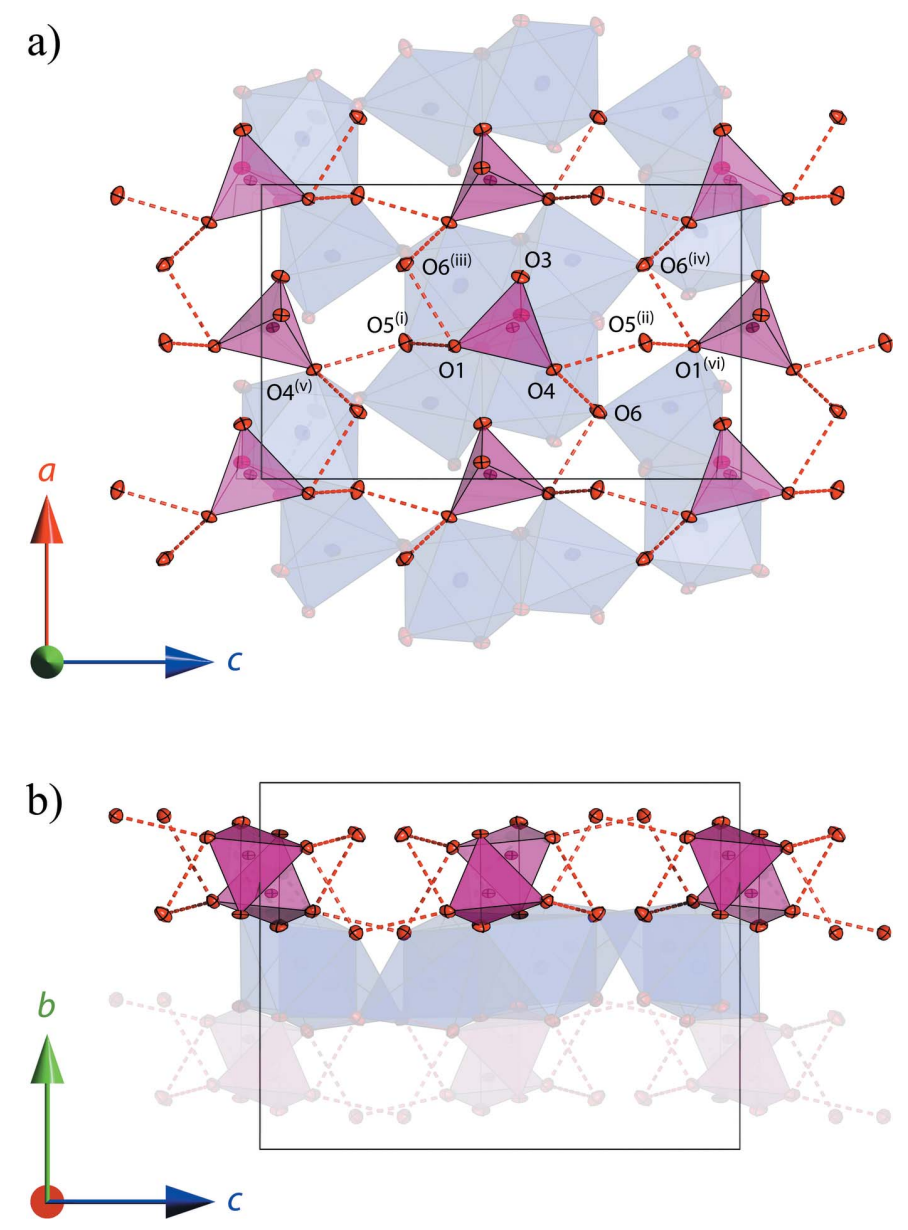

Figure 3

(a) View down the $b$ axis of the network of water-linked tetrahedral oxyanions; chains linked by O5 extend along [001] whereas crosslinkages through O6 are staggered along [100]. (b) View of the same structure along the $c$ axis. Ellipsoids are drawn at the $50 \%$ probability level. [Symmetry codes: (i) $1-x, 1-y, 1-z$; (ii) $1-x, \frac{1}{2}+y, \frac{3}{2}-z$; (iii) $\frac{1}{2}+x$, $\frac{3}{2}-y, 1-z$; (iv) $\frac{1}{2}+x, y, \frac{3}{2}-z ;$ (v) $x, \frac{3}{2}-y,-\frac{1}{2}+z$; (vi) $x, \frac{3}{2}-y, \frac{1}{2}+z$.]

along [100]. Fig. 3(a) and 3(b) depict the spatial relationship between this 'net' of water linked tetrahedra and the adjacent 'slab' of corner-linked $\mathrm{Na}-\mathrm{O}$ polyhedral clusters. The layers shown in Fig. 3(b) alternate to create the three-dimensional structure and are no doubt responsible for the macro-scale platy habit of the crystals.
There are no significant differences in the hydrogen bond geometries of the molybdate or tungstate crystals. The most recent X-ray single-crystal diffraction study of $\mathrm{Na}_{2} \mathrm{WO}_{4} \cdot 2 \mathrm{H}_{2} \mathrm{O}$ (Farrugia, 2007) implied that one of the water molecules (O5) was involved in a weaker three-centred interaction, although a similarly recent measurement of $\mathrm{Na}_{2} \mathrm{MoO}_{4} \cdot 2 \mathrm{H}_{2} \mathrm{O}$ (Capitelli et al., 2006) identified a 'normal' linear two-centred interaction for this bond. This work, using neutrons, has been able to accurately and precisely characterise the hydrogen bond geometry, showing that the latter is true for both structures; there is no bifurcated bond and all hydrogen-bonded interactions are of the linear two-centred variety. Presumably the error in Farrugia's analysis arose due to the substantial absorption correction required $\left(\mu=18.7 \mathrm{~mm}^{-1}\right)$ for an accurate structure refinement from X-ray single-crystal data.

Raman spectra of $\mathrm{Na}_{2} \mathrm{MoO}_{4} \cdot 2 \mathrm{H}_{2} \mathrm{O}$ and $\mathrm{Na}_{2} \mathrm{MoO}_{4} \cdot 2 \mathrm{D}_{2} \mathrm{O}$ were first reported by Mahadevan Pillai et al. (1997); subsequently, Luz-Lima et al. (2010) and Saraiva et al. (2013) published the Raman spectra of $\mathrm{Na}_{2} \mathrm{MoO}_{4} \cdot 2 \mathrm{H}_{2} \mathrm{O}$ and $\mathrm{Na}_{2} \mathrm{WO}_{4} \cdot 2 \mathrm{H}_{2} \mathrm{O}$ as a function of temperature $(13-300 \mathrm{~K})$ and as a function of hydrostatic pressure (to $5 \mathrm{GPa}$ ). Both compounds exhibit evidence of a 'conformational change' on cooling through $120 \mathrm{~K}$ : the molybdate appears to undergo two high-pressure phase transitions, one at $3 \mathrm{GPa}$ and the second at $4 \mathrm{GPa}$; the tungstate apparently undergoes a high-pressure phase transition at $3.9 \mathrm{GPa}$. The Raman spectra reported here (Figs. 4 and 5 and Supporting information) agree well with data in the literature (Table 3). The large blue-shifts in the internal vibrational frequencies of the deuterated water molecule are similar to the square root of the D:H mass ratio; the small blue-shifts of most of the internal modes of the tetrahedral oxyanions are consistent with stronger hydrogen bonding in the deuterated species, as expected ( $c f$. Scheiner \& Čuma, 1996; Soper \& Benmore, 2008).

\section{Synthesis and crystallization}

Coarse polycrystalline powders of $\mathrm{Na}_{2} \mathrm{MoO}_{4} \cdot 2 \mathrm{H}_{2} \mathrm{O}$ (SigmaAldrich $\mathrm{M} 1003>99.5 \%$ ) and $\mathrm{Na}_{2} \mathrm{WO}_{4} \cdot 2 \mathrm{H}_{2} \mathrm{O}$ (Sigma-Aldrich $14304>99 \%$ ) were dehydrated by drying at $673 \mathrm{~K}$ in air. The resulting anhydrous materials were characterised by Raman spectroscopy, X-ray and neutron powder diffraction (Fortes, 2015). This material was dissolved in $\mathrm{D}_{2} \mathrm{O}$ (Aldrich 151882,

Table 3

Comparison of the internal vibrational mode frequencies $\left(\mathrm{cm}^{-1}\right)$ in fully protonated and $90 \mathrm{~mol} \%$ deuterated isotopologues of $\mathrm{Na}_{2} \mathrm{MoO}_{4} \cdot 2 \mathrm{H}_{2} \mathrm{O}$ and $\mathrm{Na}_{2} \mathrm{WO}_{4} \cdot 2 \mathrm{H}_{2} \mathrm{O}$ with literature data.

\begin{tabular}{|c|c|c|c|c|c|c|}
\hline & $\mathrm{Na}_{2} \mathrm{MoO}_{4} \cdot 2 \mathrm{H}_{2} \mathrm{O}$ & & & $\mathrm{Na}_{2} \mathrm{WO}_{4} \cdot 2 \mathrm{H}_{2} \mathrm{O}$ & & \\
\hline \multirow{4}{*}{$v_{2}\left(X \mathrm{O}_{4}{ }^{2-}\right)$} & This work $\left({ }^{1} \mathrm{H}\right)$ & This work $\left({ }^{2} \mathrm{D}\right)$ & Busey \& Keller (1964) & This work $\left({ }^{1} \mathrm{H}\right)$ & This work $\left({ }^{2} \mathrm{D}\right)$ & Busey \& Keller (1964) \\
\hline & 279 & 271 & 285 & 276 & 269 & 276 \\
\hline & 319 & 315 & 325 & 324 & 321 & 325 \\
\hline & 335 & 331 & & 330 & 331 & \\
\hline$v_{4}\left(X \mathrm{O}_{4}{ }^{2-}\right)$ & 359 & 358 & & 358 & 355 & \\
\hline \multirow[t]{3}{*}{$v_{3}\left(X \mathrm{O}_{4}^{2-}\right)$} & 804 & 801 & 805 & 804 & 802 & 808 \\
\hline & 833 & 826 & 836 & 836 & 831 & 838 \\
\hline & 842 & 840 & 843 & & 840 & \\
\hline \multirow{2}{*}{$v_{1}\left(X \mathrm{O}_{4}{ }^{2-}\right)$} & & & & 891 & 889 & 893 \\
\hline & 894 & 894 & 897 & 929 & 928 & 931 \\
\hline
\end{tabular}



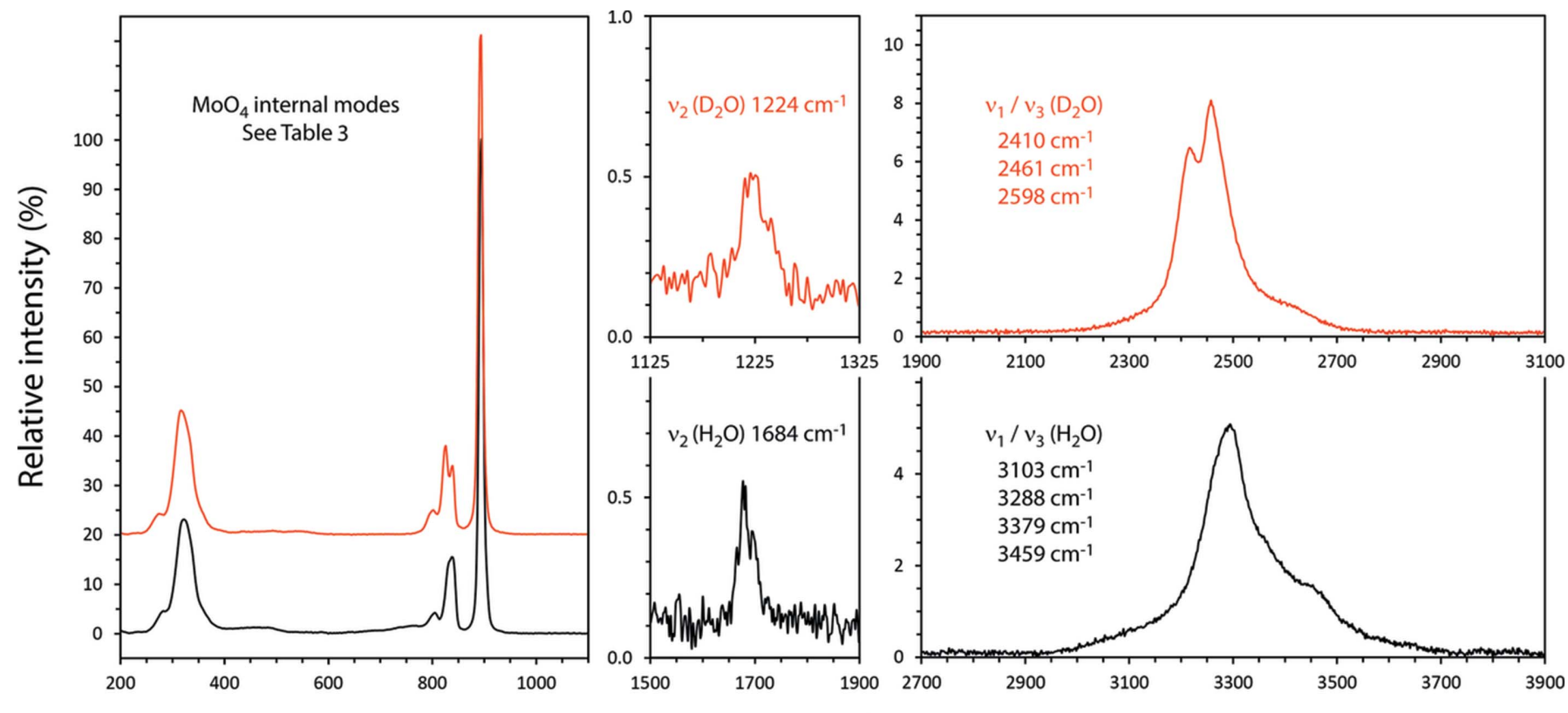

Raman shift $\left(\mathrm{cm}^{-1}\right)$

Figure 4

Raman spectra of $\mathrm{Na}_{2} \mathrm{MoO}_{4} \cdot 2 \mathrm{H}_{2} \mathrm{O}$ and $\mathrm{Na}_{2} \mathrm{MoO}_{4} \cdot 2 \mathrm{D}_{2} \mathrm{O}$ in the range $200-3900 \mathrm{~cm}^{-1}$. Band positions and vibrational assignments are indicated (see also Table 3). Vertical scales show intensities relative to $v_{1}\left(\mathrm{XO}_{4}{ }^{2-}\right)$.

99.9 atom $\%$ D) and twice recrystallized by gentle evaporation at $323 \mathrm{~K}$. The molybdate crystallised with a coarse platy habit whereas the tungstate was deposited as a finer-grained material. Once the supernatant liquid was decanted, the residue was air dried on filter paper and then ground to a fine powder with an agate pestle and mortar. The powders were loaded into standard vanadium sample-holder tubes of internal diameter $11 \mathrm{~mm}$ to a depth not less than $20 \mathrm{~mm}$ (this being the vertical neutron beam dimension at the sample position). Accurate volumes and masses were determined after the diffraction measurements were complete and used to correct the data for self-shielding. The level of deuteration was determined by Raman spectroscopy (see below) to be $\sim 91 \%$ for both compounds.
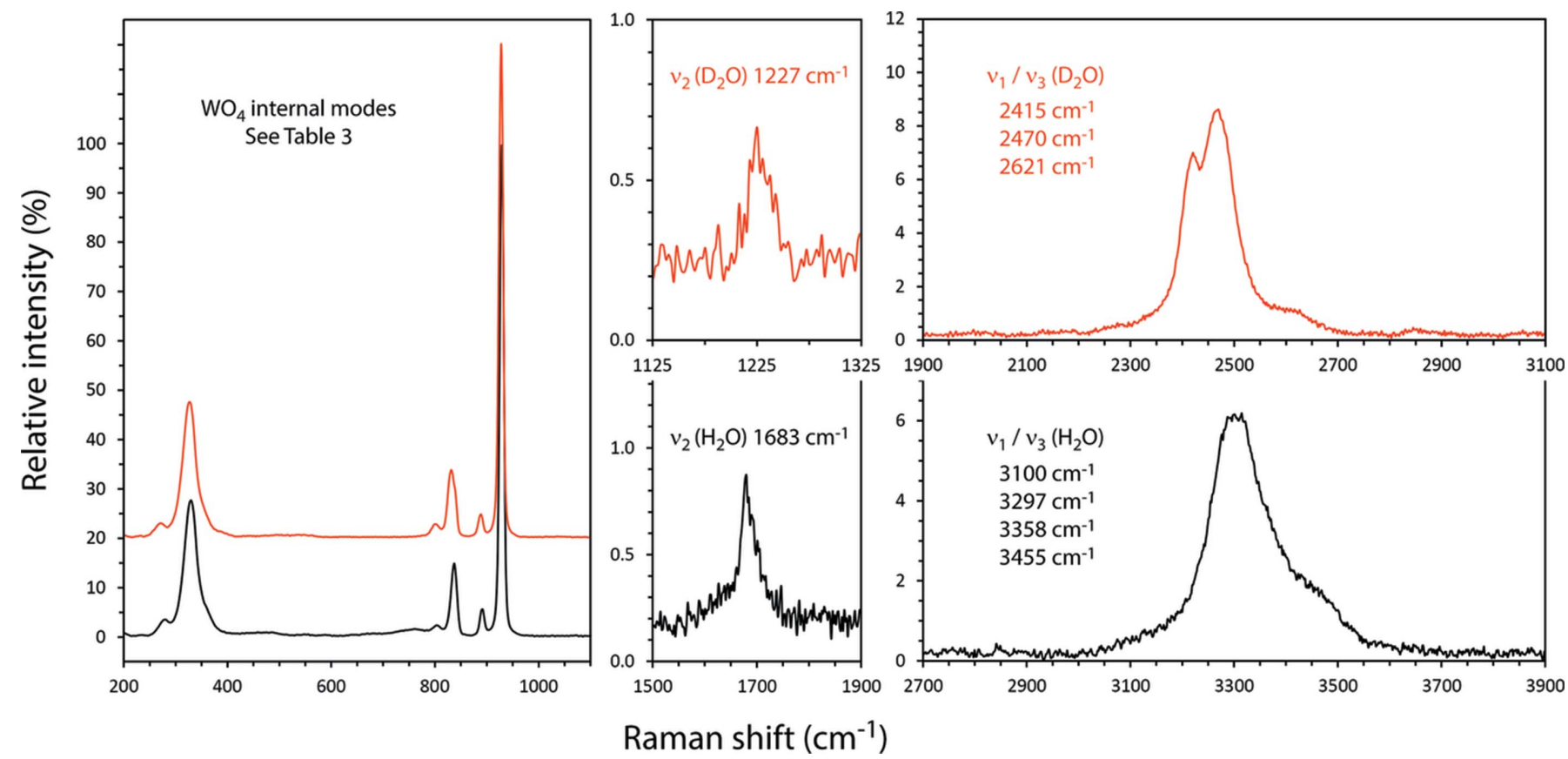

Figure 5

Raman spectra of $\mathrm{Na}_{2} \mathrm{WO}_{4} \cdot 2 \mathrm{H}_{2} \mathrm{O}$ and $\mathrm{Na}_{2} \mathrm{WO}_{4} \cdot 2 \mathrm{D}_{2} \mathrm{O}$ in the range $200-3900 \mathrm{~cm}^{-1}$. Band positions and vibrational assignments are indicated (see also Table 3). Vertical scales show intensities relative to $v_{1}\left(\mathrm{XO}_{4}{ }^{2-}\right)$. 
Table 4

Experimental details.

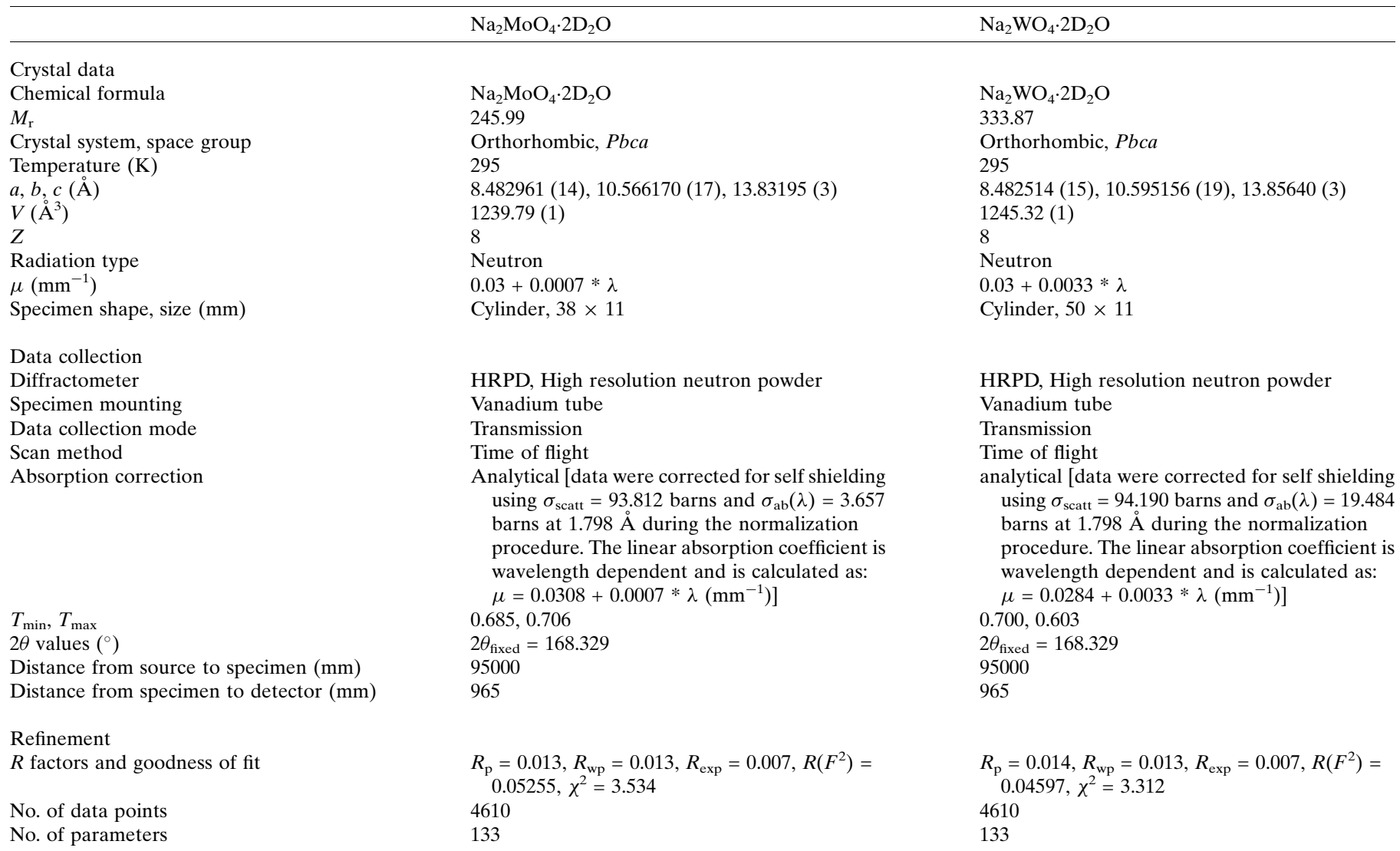

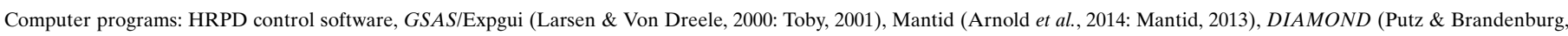
2006) and publCIF (Westrip, 2010).

Raman spectra were acquired with a B\&WTek $i$-Raman plus portable spectrometer; this device uses a $532 \mathrm{~nm}$ laser $(37 \mathrm{~mW}$ power at the fiber-optic probe tip) to stimulate

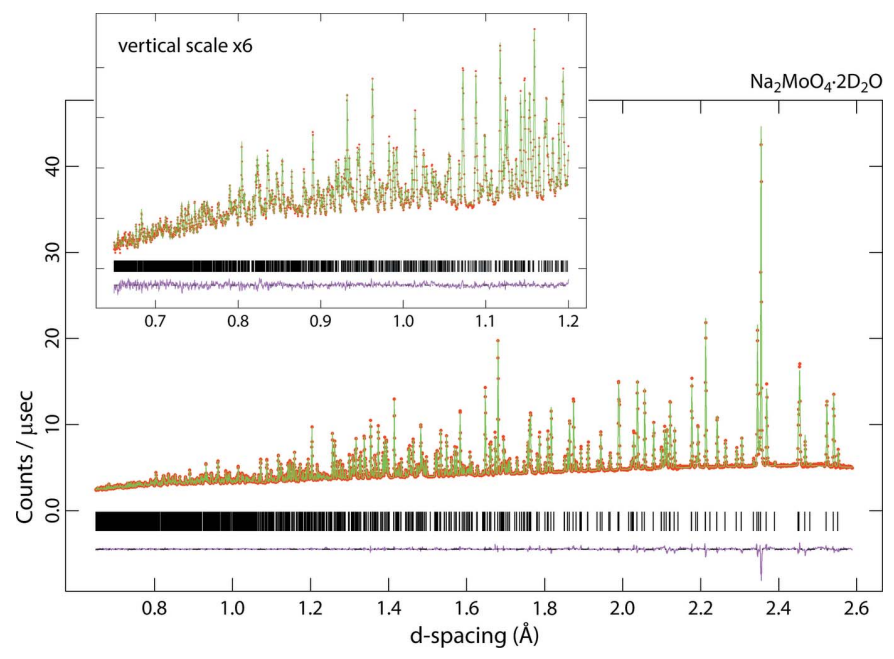

Figure 6

Neutron powder diffraction data for $\mathrm{Na}_{2} \mathrm{MoO}_{4} \cdot 2 \mathrm{D}_{2} \mathrm{O}$; red points are the observations, the green line is the calculated profile and the pink line beneath the diffraction pattern represents Obs-Calc. Vertical black tick marks report the expected positions of the Bragg peaks. The inset shows the data measured at short flight times (i.e. small $d$-spacings).
Raman scattering, which is measured in the range 170$4000 \mathrm{~cm}^{-1}$ with a spectral resolution of $3 \mathrm{~cm}^{-1}$. Data were collected for $600 \mathrm{sec}$ at $17 \mathrm{~mW}$ for $\mathrm{Na}_{2} \mathrm{MoO}_{4} \cdot 2 \mathrm{H}_{2} \mathrm{O}$ (as

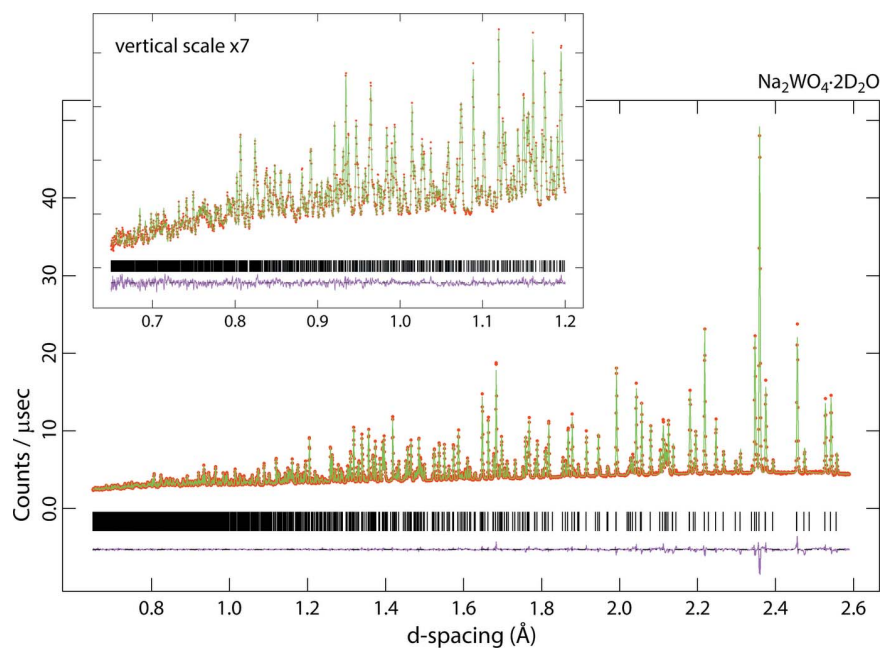

Figure 7

Neutron powder diffraction data for $\mathrm{Na}_{2} \mathrm{WO}_{4} \cdot 2 \mathrm{D}_{2} \mathrm{O}$; red points are the observations, the green line is the calculated profile and the pink line beneath the diffraction pattern represents Obs-Calc. Vertical black tick marks report the expected positions of the Bragg peaks. The inset shows the data measured at short flight times (i.e. small $d$-spacings). 
bought), $180 \mathrm{sec}$ at $37 \mathrm{~mW}$ for $\mathrm{Na}_{2} \mathrm{MoO}_{4} \cdot 2 \mathrm{D}_{2} \mathrm{O}, 300 \mathrm{sec}$ at $17 \mathrm{~mW}$ for $\mathrm{Na}_{2} \mathrm{WO}_{4} \cdot 2 \mathrm{H}_{2} \mathrm{O}$ (as bought) and $220 \mathrm{sec}$ at $37 \mathrm{~mW}$ for $\mathrm{Na}_{2} \mathrm{WO}_{4} \cdot 2 \mathrm{D}_{2} \mathrm{O}$; after summation, the background was removed and peaks fitted using Pseudo-Voigt functions in OriginPro (OriginLab, Northampton MA). These data are provided as an electronic supplement in the form of an ASCII file. Small quantities of ordinary hydrogen were found to be present in both specimens, the proportion being determined by the ratio of the areas under the $v_{1} / v_{3}\left(\mathrm{H}_{2} \mathrm{O}\right)$ bands after normalisation relative to the height of the strong $v_{1}\left(\mathrm{XO}_{4}{ }^{2-}\right)$ band. The molar abundance of ${ }^{1} \mathrm{H}$ was used to correct the diffraction data for absorption (see below) and to ensure accurate refinement of the structure (see Refinement).

Time-of-flight neutron diffraction patterns were collected at $295 \mathrm{~K}$ using the High Resolution Powder Diffractometer, HRPD (Ibberson, 2009), at the ISIS spallation neutron source, Harwell Campus, Oxfordshire, UK. Data were acquired in the range of neutron flight times from 30-130 msec (equivalent to neutron wavelengths of $1.24-5.36 \AA$ ) for $15.17 \mathrm{hr}$ from the molybdate and $14.40 \mathrm{hr}$ from the tungstate, equivalent to 615 and $590 \mu \mathrm{Ahr}$ of integrated proton beam current, respectively. These data sets were normalized to the incident spectrum and corrected for detector efficiency by reference to a V:Nb nullscattering standard and then subsequently corrected for the sample-specific and wavelength-dependent self-shielding using Mantid (Arnold et al., 2014: Mantid, 2013). In the case of the molybdate, the number density of the specimen was determined to be $3.28 \mathrm{~mol} \mathrm{~nm}^{-3}$, with a scattering cross section, allowing for the water being $9.1 \mathrm{~mol} \%{ }^{1} \mathrm{H}, \sigma_{\text {scatt }}=$ $93.81 \mathrm{~b}$ and an absorption cross section, $\sigma_{\mathrm{abs}}=3.66 \mathrm{~b}$; for the tungstate, the number density was $3.01 \mathrm{~mol} \mathrm{~nm}^{-3}$, the scattering cross section, allowing for the water being $8.6 \mathrm{~mol} \%$ ${ }^{1} \mathrm{H}, \sigma_{\text {scatt }}=94.19 \mathrm{~b}$ and $\sigma_{\text {abs }}=19.48 \mathrm{~b}$. Diffraction data were exported in GSAS format and analysed with the GSAS/Expgui Rietveld package (Larsen \& Von Dreele, 2000: Toby, 2001). The fitted diffraction data are shown in Figs. 6 and 7.

\section{Refinement}

Profile refinements were done using GSAS/Expgui (Larsen \& Von Dreele, 2000; Toby, 2001) starting from the coordinates reported by Farrugia (2007). Statistically significant anisotropic displacement parameters were refined for all atoms. An assumption was made that ${ }^{1} \mathrm{H}$ was uniformly distributed on all ${ }^{2} \mathrm{D}$ sites, so the neutron scattering length of ${ }^{2} \mathrm{D}$ was edited in GSAS in accordance with the concentration of ${ }^{1} \mathrm{H}$ determined by Raman spectroscopy; for the molybdate a value of $5.776 \mathrm{fm}$ was used, and for the tungstate a value of $5.724 \mathrm{fm}$ was adopted. Crystal data, data collection and structure refinement details are summarized in Table 4.

\section{Acknowledgements}

The author thanks the STFC ISIS facility for beam-time access and acknowledges financial support from STFC (grant No. ST/K000934/1).

\section{References}

Aksenov, S. M., Rastsvetaeva, R. K., Chukanov, N. V. \& Kolitsch, U. (2014). Acta Cryst. B70, 768-775.

Arnold, O., et al. (2014). Nucl. Instrum. Methods Phys. Res. A764, 156-166.

Atovmyan, L. O. \& D'yachenko, O. A. (1969). J. Struct. Chem. 10, 416-418.

Beurskens, G. \& Jeffrey, G. A. (1961). J. Chem. Phys. 41, 924-929.

Busey, R. H. \& Keller, O. L. (1964). J. Chem. Phys. 41, 215-225.

Capitelli, F., Selim, M. \& Mukherjea, K. K. (2006). Asian J. Chem. 18, 2856-2860.

Císařová, I., Skála, R., Ondruš, P. \& Drábek, M. (2001). Acta Cryst. E57, i32-i34.

Clarke, F. W. (1877). Am. J. Sci. Ser. III, 14, 280-286.

Delafontaine, M. (1865). J. Prakt. Chem. 95, 136-145.

Farrugia, L. J. (2007). Acta Cryst. E63, i142.

Fleck, M., Schwendtner, K. \& Hensler, A. (2006). Acta Cryst. C62, $\mathrm{m} 122-\mathrm{m} 125$.

Fortes, A. D. (2015). Acta Cryst. E71, 592-596.

Funk, R. (1900). Ber. Dtsch Chem. Ges. 33, 3696-3703.

Ibberson, R. M. (2009). Nucl. Instrum. Methods Phys. Res. A, 600, 4749.

Kahlenberg, V. (2012). Z. Kristallogr. 227, 621-628.

Klevtsova, R. F., Glinskaya, L. A., Perepelitsa, A. P., Ishchenko, V. N. \& Klevtsov, P. V. (1990). Sov. Phys. Crystallogr. 35, 643-646.

Klevtsov, P. V., Glinskaya, L. A., Klevtsova, R. F. \& Aleksandrov, K. S. (1997). J. Struct. Chem. 38, 615-619.

Larsen, A. C. \& Von Dreele, R. B. (2000). General Structure Analysis System $(G S A S)$. Los Alamos National Laboratory Report LAUR 86-748, Los Alamos, New Mexico. http://www.ncnr.NIST.gov/Xtal/ software/GSAS.html.

Luz-Lima, C., Saraiva, G. D., Souza Filho, A. G., Paraguassu, W., Freirea, P. T. C. \& Mendes Filhoa, J. (2010). J. Raman Spectrosc. 41, 576-581.

Mahadevan Pillai, V. P., Pradeep, T., Bushiri, M. J., Jayasree, R. S. \& Nayar, V. U. (1997). Spectrochim. Acta A53, 867-876.

Mantid (2013). Manipulation and Analysis Toolkit for Instrument Data.; Mantid Project. http://dx.doi.org/10.5286/SOFTWARE/ MANTID.

Marignac, J. C. (1863). Ann. Chim. Phys. $3^{\text {eme }}$ Ser. 69, 5-86.

Matsumoto, K., Kobayashi, A. \& Sasaki, Y. (1975). Bull. Chem. Soc. Jpn, 48, 1009-1013.

Mereiter, K. (2013). Acta Cryst. E69, i77-i78.

Mirzoev, R. S., Shetov, R. A., Ligidov, M. Kh. \& El'mesova, R. M. (2010). Russ. J. Inorg. Chem. 55, 96-102.

Mitra, R. P. \& Verma, H. K. L. (1969). Indian J. Chem. 7, 598-602.

Okada, K., Morikawa, H., Marumo, F. \& Iwai, S. I. (1974). Bull. Tokyo Inst. Technol. 120, 7-11.

Pistorius, C. W. F. T. \& Sharp, W. E. (1961). Acta Cryst. 14, 316-317.

Putz, H. \& Brandenburg, K. (2006). DIAMOND. Crystal Impact, Bonn, Germany.

Rammelsberg, K. F. A. (1855). In Handbuch der Krystallographischen Chemie. Berlin: P. Jeanrenaud.

Saraiva, G. D., Luz-Lima, C., Freire, P. T. C., Ramiro de Castro, A. J., de Sousa, G. P., Melo, F. E. A., Silva, J. H. \& Mendes Filho, J. (2013). J. Mol. Struct. 1033, 154-161.

Scheiner, S. \& Čuma, C. (1996). J. Am. Chem. Soc. 118, 1511-1521.

Sears, V. F. (1992). Neutron News, 3, 26-37.

Sharma, R. P., Bala, R., Sharma, R. \& Bond, A. D. (2005). Acta Cryst. C61, m356-m358.

Smith, G. (2013). Acta Cryst. C69, 1472-1477.

Smith, G. \& Wermuth, U. D. (2014). Acta Cryst. C70, 738-741.

Soper, A. K. \& Benmore, C. J. (2008). Phys. Rev. Lett. 101, 065502.

Svanberg, L. \& Struve, H. (1848). Phil. Mag. 3rd Ser. 33, 409-434.

Toby, B. H. (2001). J. Appl. Cryst. 34, 210-213.

Ullik, F. (1867). Justus Liebigs Ann. Chem. 144, 204-233.

Weil, M. \& Bonneau, B. (2014). Acta Cryst. E70, 54-57. 
Westrip, S. P. (2010). J. Appl. Cryst. 43, 920-925.

Zambonini, F. (1923). Z. Kristallogr. 58, 266-292.

Zenker, F. E. (1853). J. Prakt. Chem. 58, 486-492.
Zhilova, S. B., Karov, Z. G. \& El'mesova, R. M. (2008). Russ. J. Inorg. Chem. 53, 628-635. 


\section{supporting information}

Acta Cryst. (2015). E71, 799-806 [doi:10.1107/S2056989015011354]

\section{Crystal structures of deuterated sodium molybdate dihydrate and sodium tungstate dihydrate from time-of-flight neutron powder diffraction}

\section{A. Dominic Fortes}

\section{Computing details}

For both compounds, data collection: HRPD control software; cell refinement: GSAS/Expgui (Larsen \& Von Dreele, 2000: Toby, 2001); data reduction: Mantid (Arnold et al., 2014: Mantid, 2013); program(s) used to solve structure: $\mathrm{n} / \mathrm{a}$; program(s) used to refine structure: GSAS/Expgui (Larsen \& Von Dreele, 2000: Toby, 2001); molecular graphics: DIAMOND (Putz \& Brandenburg, 2006); software used to prepare material for publication: publCIF (Westrip, 2010).

(Na2MoO4.2D2O) Disodium molybdenum(VI) oxide dihydrate

\section{Crystal data}

$\mathrm{Na}_{2} \mathrm{MoO}_{4} \cdot 2 \mathrm{D}_{2} \mathrm{O}$

$M_{r}=245.99$

Orthorhombic, $\mathrm{Pbca}$

Hall symbol: -P 2ac $2 \mathrm{ab}$

$a=8.482961(14) \AA$

$b=10.566170(17) \AA$

$c=13.83195$ (3) $\AA$

$V=1239.79(1) \AA^{3}$

$Z=8$

\section{Data collection}

HRPD, High resolution neutron powder diffractometer

Radiation source: ISIS Facility, Neutron spallation source

Specimen mounting: vanadium tube

Data collection mode: transmission

Scan method: time of flight

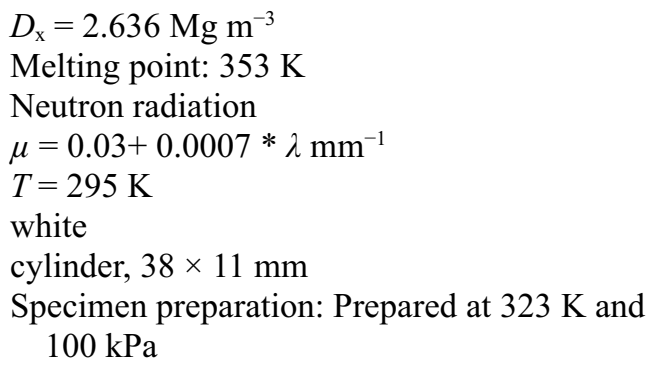

\footnotetext{
Absorption correction: analytical

Data were corrected for self shielding using $\sigma_{\text {scatt }}$ $=93.812$ barns and $\sigma_{\mathrm{ab}}(\lambda)=3.657$ barns at 1.798 A during the normalisation procedure. The linear absorption coefficient is wavelength dependent and is calculated as: $\mu=0.0308+$ $0.0007 * \lambda\left[\mathrm{mm}^{-1}\right]$

$T_{\min }=0.685, T_{\max }=0.706$

$2 \theta_{\text {fixed }}=168.329$

Distance from source to specimen: $95000 \mathrm{~mm}$

Distance from specimen to detector: $965 \mathrm{~mm}$
} 


\section{Refinement}

Least-squares matrix: full

$R_{\mathrm{p}}=0.013$

$R_{\text {wp }}=0.013$

$R_{\text {exp }}=0.007$

$R\left(F^{2}\right)=0.05255$

$\chi^{2}=3.534$

4610 data points

Excluded region(s): none
Profile function: TOF profile function \#3 (21 terms). Profile coefficients for exp pseudovoigt convolution [Von Dreele, 1990 (unpublished)] $(\alpha)=0.1414,\left(\beta_{0}\right)=0.026250,\left(\beta_{1}\right)=0.004690$, $\left(\sigma_{0}\right)=0,\left(\sigma_{1}\right)=194.5,\left(\sigma_{2}\right)=13.5,\left(\gamma_{0}\right)=0,\left(\gamma_{1}\right)=$ $0,\left(\gamma_{2}\right)=0,\left(\gamma_{2 \mathrm{~s}}\right)=0,\left(\gamma_{\mathrm{le}}\right)=0,\left(\gamma_{2 \mathrm{e}}\right)=0,\left(\varepsilon_{\mathrm{i}}\right)=0$, $\left(\varepsilon_{\mathrm{a}}\right)=0,\left(\varepsilon_{\mathrm{A}}\right)=0,\left(\gamma_{11}\right)=0.057,\left(\gamma_{22}\right)=0,\left(\gamma_{33}\right)=$ $0.059,\left(\gamma_{12}\right)=-0.087,\left(\gamma_{13}\right)=-0.014,\left(\gamma_{23}\right)=$ -0.018 . Peak tails ignored where intensity $<0.0010 \mathrm{x}$ peak. Aniso. broadening axis 0.00 .0 1.0

133 parameters

0 restraints

0 constraints

$(\Delta / \sigma)_{\max }=0.03$

Background function: GSAS Background function number 1 with 12 terms. Shifted Chebyshev function of 1st kind 1: 4.30598, 2: 1.54022, 3: -0.237828 4: $-6.992080 \times 10^{-2}, 5$ : $-0.113274,6:-1.736560 \times 10^{-2}, 7:-1.996810 \times 10^{-2}$, 8: $2.118030 \times 10^{-5}, 9:-4.698340 \times 10^{-3}, 10$ : $-2.646770 \times 10^{-2}, 11: 2.772870 \times 10^{-2}, 12$ : $-1.690170 \times 10^{-3}$

Fractional atomic coordinates and isotropic or equivalent isotropic displacement parameters $\left(\AA^{2}\right)$

\begin{tabular}{lllll}
\hline & $x$ & $y$ & $z$ & $U_{\text {iso }} * / U_{\text {eq }}$ \\
\hline Mo1 & $0.51477(10)$ & $0.80193(8)$ & $0.52313(8)$ & 0.01137 \\
Na1 & $0.3438(3)$ & $0.4964(2)$ & $0.58515(17)$ & 0.02371 \\
Na2 & $0.7433(2)$ & $0.5509(2)$ & $0.64802(16)$ & 0.0216 \\
O1 & $0.45103(15)$ & $0.82353(12)$ & $0.40216(9)$ & 0.01917 \\
O2 & $0.55667(15)$ & $0.64011(10)$ & $0.54111(10)$ & 0.01665 \\
O3 & $0.68676(15)$ & $0.89087(11)$ & $0.53936(11)$ & 0.02282 \\
O4 & $0.37187(15)$ & $0.85121(12)$ & $0.60907(10)$ & 0.0194 \\
O5 & $0.53793(19)$ & $0.40846(16)$ & $0.70077(14)$ & 0.0252 \\
O6 & $0.2281(2)$ & $0.64176(17)$ & $0.70081(11)$ & 0.02505 \\
D51 & $0.5576(2)$ & $0.32908(18)$ & $0.66668(13)$ & 0.03656 \\
D52 & $0.5585(2)$ & $0.39149(15)$ & $0.76825(14)$ & 0.03068 \\
D61 & $0.1235(2)$ & $0.64696(14)$ & $0.67235(12)$ & 0.03034 \\
D62 & $0.27890(19)$ & $0.71840(16)$ & $0.67765(12)$ & 0.03232
\end{tabular}

Atomic displacement parameters $\left(\AA^{2}\right)$

\begin{tabular}{lllllll}
\hline & $U^{11}$ & $U^{22}$ & $U^{33}$ & $U^{12}$ & $U^{13}$ & $U^{23}$ \\
\hline Mo1 & $0.0103(6)$ & $0.0083(5)$ & $0.0156(6)$ & $0.0001(4)$ & $0.0009(5)$ & $0.0003(5)$ \\
$\mathrm{Na} 1$ & $0.0249(13)$ & $0.0213(11)$ & $0.0250(15)$ & $-0.0011(10)$ & $0.0026(10)$ & $0.0012(9)$ \\
$\mathrm{Na} 2$ & $0.0196(12)$ & $0.0180(12)$ & $0.0272(14)$ & $-0.0037(9)$ & $0.0008(9)$ & $-0.0006(10)$ \\
$\mathrm{O} 1$ & $0.0188(7)$ & $0.0191(7)$ & $0.0196(8)$ & $0.0025(6)$ & $0.0004(6)$ & $0.0017(6)$ \\
$\mathrm{O} 2$ & $0.0161(6)$ & $0.0086(6)$ & $0.0252(8)$ & $-0.0008(6)$ & $-0.0019(6)$ & $0.0017(6)$ \\
$\mathrm{O} 3$ & $0.0197(7)$ & $0.0199(7)$ & $0.0289(9)$ & $-0.0079(6)$ & $-0.0020(6)$ & $-0.0022(7)$
\end{tabular}


supporting information

\begin{tabular}{lllllll} 
O4 & $0.0187(6)$ & $0.0163(6)$ & $0.0233(8)$ & $0.0040(6)$ & $0.0050(6)$ & $-0.0011(6)$ \\
O5 & $0.0272(9)$ & $0.0207(9)$ & $0.0277(10)$ & $-0.0006(7)$ & $-0.0036(8)$ & $0.0001(8)$ \\
O6 & $0.0264(9)$ & $0.0257(9)$ & $0.0231(10)$ & $-0.0018(8)$ & $-0.0031(7)$ & $0.0060(7)$ \\
D51 & $0.0432(11)$ & $0.0272(9)$ & $0.0393(11)$ & $0.0030(8)$ & $-0.0107(9)$ & $-0.0006(9)$ \\
D52 & $0.0399(9)$ & $0.0292(8)$ & $0.0229(8)$ & $0.0008(8)$ & $-0.0003(8)$ & $0.0027(8)$ \\
D61 & $0.0233(9)$ & $0.0340(9)$ & $0.0337(9)$ & $0.0004(7)$ & $-0.0062(8)$ & $0.0030(8)$ \\
D62 & $0.0338(10)$ & $0.0248(8)$ & $0.0384(12)$ & $-0.0056(8)$ & $-0.0024(8)$ & $0.0028(8)$ \\
\hline
\end{tabular}

Geometric parameters $\left(\AA,^{\circ}\right)$

\begin{tabular}{|c|c|c|c|}
\hline Mo1-O1 & $1.7732(17)$ & $\mathrm{Na} 2-\mathrm{O}^{\mathrm{v}}$ & $2.339(3)$ \\
\hline $\mathrm{Mo} 1-\mathrm{O} 2$ & $1.7640(14)$ & $\mathrm{Na} 2-\mathrm{O} 5$ & $2.415(3)$ \\
\hline $\mathrm{Mo1}-\mathrm{O} 3$ & 1.7499 (16) & $\mathrm{Na} 2-\mathrm{O}^{\mathrm{vi}}$ & $2.305(3)$ \\
\hline Mo1-O4 & $1.7759(17)$ & O5-D51 & $0.9766(19)$ \\
\hline $\mathrm{Na} 1-\mathrm{O} 2$ & $2.437(3)$ & O5-D52 & 0.9664 (18) \\
\hline $\mathrm{Na} 1-\mathrm{O} 2^{\mathrm{i}}$ & $2.417(3)$ & O6-D61 & $0.9722(16)$ \\
\hline $\mathrm{Na} 1-\mathrm{O} 3^{\mathrm{ii}}$ & $2.482(3)$ & O6-D62 & $0.9719(18)$ \\
\hline $\mathrm{Na} 1-\mathrm{O} 4^{\mathrm{iii}}$ & $2.410(3)$ & $\mathrm{D} 51-\mathrm{O} 1^{\mathrm{i}}$ & $1.874(2)$ \\
\hline $\mathrm{Na} 1-\mathrm{O} 5$ & $2.476(2)$ & $\mathrm{D} 52-\mathrm{O} 4^{\mathrm{vii}}$ & $1.846(3)$ \\
\hline $\mathrm{Na} 1-\mathrm{O} 6$ & $2.426(3)$ & $\mathrm{D} 61-\mathrm{O} 1^{\mathrm{ii}}$ & $1.816(2)$ \\
\hline $\mathrm{Na} 2-\mathrm{O} 1^{\text {iv }}$ & $2.312(3)$ & $\mathrm{D} 62-\mathrm{O} 4$ & $1.868(3)$ \\
\hline $\mathrm{Na} 2-\mathrm{O} 2$ & $2.363(3)$ & & \\
\hline $\mathrm{O} 1-\mathrm{Mo1}-\mathrm{O} 2$ & $108.62(8)$ & $\mathrm{O} 2^{\mathrm{i}}-\mathrm{Na} 1-\mathrm{O} 6$ & $174.75(13)$ \\
\hline $\mathrm{O} 1-\mathrm{Mo1}-\mathrm{O} 3$ & $107.83(8)$ & $\mathrm{O} 4{ }^{\mathrm{iii}}-\mathrm{Na} 1-\mathrm{O} 5$ & $100.22(10)$ \\
\hline $\mathrm{O} 1-\mathrm{Mo1}-\mathrm{O} 4$ & $112.69(8)$ & $\mathrm{O} 4{ }^{\mathrm{iii}}-\mathrm{Na} 1-\mathrm{O} 6$ & $90.30(9)$ \\
\hline $\mathrm{O} 2-\mathrm{Mo} 1-\mathrm{O} 3$ & $109.54(7)$ & $\mathrm{O} 5-\mathrm{Na} 1-\mathrm{O} 6$ & $94.63(10)$ \\
\hline $\mathrm{O} 2-\mathrm{Mo} 1-\mathrm{O} 4$ & $109.11(8)$ & $\mathrm{O} 1{ }^{\mathrm{iv}}-\mathrm{Na} 2-\mathrm{O} 2$ & $95.39(9)$ \\
\hline $\mathrm{O} 3-\mathrm{Mo} 1-\mathrm{O} 4$ & $109.01(8)$ & $\mathrm{O} 1^{\mathrm{iv}}-\mathrm{Na} 2-\mathrm{O}^{\mathrm{v}}$ & $91.65(9)$ \\
\hline $\mathrm{O} 2-\mathrm{Na} 1-\mathrm{O} 2^{\mathrm{i}}$ & $86.12(8)$ & $\mathrm{O} 1^{\mathrm{iv}}-\mathrm{Na} 2-\mathrm{O} 5$ & $176.34(12)$ \\
\hline $\mathrm{O} 2-\mathrm{Na} 1-\mathrm{O} 3^{\mathrm{ii}}$ & $85.70(9)$ & $\mathrm{O} 1^{\mathrm{iv}}-\mathrm{Na} 2-\mathrm{O}^{\mathrm{vi}}$ & $94.37(9)$ \\
\hline $\mathrm{O} 2-\mathrm{Na} 1-\mathrm{O} 4^{\mathrm{iii}}$ & $173.42(12)$ & $\mathrm{O} 2-\mathrm{Na} 2-\mathrm{O}^{\mathrm{v}}$ & $93.22(9)$ \\
\hline $\mathrm{O} 2-\mathrm{Na} 1-\mathrm{O} 5$ & $84.40(9)$ & $\mathrm{O} 2-\mathrm{Na} 2-\mathrm{O} 5$ & $87.38(8)$ \\
\hline $\mathrm{O} 2-\mathrm{Na} 1-\mathrm{O} 6$ & $94.02(10)$ & $\mathrm{O} 2-\mathrm{Na} 2-\mathrm{O}^{\mathrm{vi}}$ & $111.35(10)$ \\
\hline $\mathrm{O} 3^{\mathrm{ii}}-\mathrm{Na} 1-\mathrm{O} 2^{\mathrm{i}}$ & $88.43(9)$ & $\mathrm{O} 3^{\mathrm{v}}-\mathrm{Na} 2-\mathrm{O} 5$ & $85.79(9)$ \\
\hline 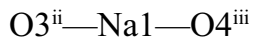 & $89.62(9)$ & $\mathrm{O}^{\mathrm{v}}-\mathrm{Na} 2-\mathrm{O}^{\mathrm{vi}}$ & $153.97(12)$ \\
\hline $\mathrm{O} 3^{\mathrm{ii}-\mathrm{Na} 1-\mathrm{O} 5}$ & $170.10(11)$ & $\mathrm{O} 5-\mathrm{Na} 2-\mathrm{O}^{\mathrm{vi}}$ & $86.84(10)$ \\
\hline $\mathrm{O} 3{ }^{\mathrm{ii}}-\mathrm{Na} 1-\mathrm{O} 6$ & $86.35(9)$ & D51-O5-D52 & $106.0(2)$ \\
\hline $\mathrm{O} 2^{\mathrm{i}}-\mathrm{Na} 1-\mathrm{O} 4^{\mathrm{iii}}$ & $89.13(9)$ & D61-O6-D62 & $103.0(2)$ \\
\hline $\mathrm{O} 2^{\mathrm{i}}-\mathrm{Na} 1-\mathrm{O} 5$ & $90.61(10)$ & & \\
\hline
\end{tabular}

Symmetry codes: (i) $-x+1,-y+1,-z+1$; (ii) $x-1 / 2,-y+3 / 2,-z+1$; (iii) $-x+1 / 2, y-1 / 2, z$; (iv) $x+1 / 2,-y+3 / 2,-z+1$; (v) $-x+3 / 2, y-1 / 2, z$; (vi) $x+1 / 2, y$, $-z+3 / 2$; (vii) $-x+1, y-1 / 2,-z+3 / 2$.

(Na2WO4.2D2O) Disodium tungsten(VI) oxide dihydrate

Crystal data

$\mathrm{Na}_{2} \mathrm{WO}_{4} \cdot 2 \mathrm{D}_{2} \mathrm{O}$

Orthorhombic, $\mathrm{Pbca}$

$M_{r}=333.87$

Hall symbol: -P 2ac 2ab 
$a=8.482514(15) \AA$

$b=10.595156(19) \AA$

$c=13.85640(3) \AA$

$V=1245.32(1) \AA^{3}$

$Z=8$

$D_{\mathrm{x}}=3.562 \mathrm{Mg} \mathrm{m}^{-3}$

Melting point: $373 \mathrm{~K}$

Data collection

HRPD, High resolution neutron powder diffractometer

Radiation source: ISIS Facility, Neutron spallation source

Specimen mounting: vanadium tube Data collection mode: transmission Scan method: time of flight

\section{Refinement}

Least-squares matrix: full

$R_{\mathrm{p}}=0.014$

$R_{\text {wp }}=0.013$

$R_{\text {exp }}=0.007$

$R\left(F^{2}\right)=0.04597$

$\chi^{2}=3.312$

4610 data points

Excluded region(s): none
Neutron radiation

$\mu=0.03+0.0033 * \lambda \mathrm{mm}^{-1}$

$T=295 \mathrm{~K}$

white

cylinder, $50 \times 11 \mathrm{~mm}$

Specimen preparation: Prepared at $323 \mathrm{~K}$ and $100 \mathrm{kPa}$
Absorption correction: analytical
Data were corrected for self shielding using $\sigma_{\text {scatt }}$ $=94.190$ barns and $\sigma_{\mathrm{ab}}(\lambda)=19.484$ barns at $1.798 \AA$ A during the normalisation procedure. The linear absorption coefficient is wavelength dependent and is calculated as: $\mu=0.0284+$ $0.0033 * \lambda\left[\mathrm{mm}^{-1}\right]$
$T_{\min }=0.603, T_{\max }=0.700$
$2 \theta_{\text {fixed }}=168.329$

Distance from source to specimen: $95000 \mathrm{~mm}$

Distance from specimen to detector: $965 \mathrm{~mm}$

Profile function: TOF profile function \#3 (21 terms). Profile coefficients for exp pseudovoigt convolution [Von Dreele, 1990 (unpublished)] $(\alpha)=0.1414,\left(\beta_{0}\right)=0.026250,\left(\beta_{1}\right)=0.004690$, $\left(\sigma_{0}\right)=0,\left(\sigma_{1}\right)=322.9,\left(\sigma_{2}\right)=15.7,\left(\gamma_{0}\right)=0,\left(\gamma_{1}\right)=$ $0,\left(\gamma_{2}\right)=0,\left(\gamma_{2 \mathrm{~s}}\right)=0,\left(\gamma_{1 \mathrm{e}}\right)=0,\left(\gamma_{2 \mathrm{e}}\right)=0,\left(\varepsilon_{\mathrm{i}}\right)=0$, $\left(\varepsilon_{\mathrm{a}}\right)=0,\left(\varepsilon_{\mathrm{A}}\right)=0,\left(\gamma_{11}\right)=0.023,\left(\gamma_{22}\right)=0,\left(\gamma_{33}\right)=$ $0.006,\left(\gamma_{12}\right)=0.050,\left(\gamma_{13}\right)=0.016,\left(\gamma_{23}\right)=0.017$. Peak tails ignored where intensity $<0.0010 \mathrm{x}$ peak. Aniso. broadening axis 0.00 .01 .0

133 parameters

0 restraints

0 constraints

$(\Delta / \sigma)_{\max }=0.04$

Background function: GSAS Background function number 1 with 12 terms. Shifted Chebyshev function of 1st kind 1: 3.91163, 2: 1.22805, 3: $-0.206144,4:-8.53351 \times 10^{-2}, 5$ : $-9.966470 \times 10^{-2}, 6:-1.847470 \times 10^{-2}, 7$ : $-1.38195 \times 10^{-2}, 8: 9.956170 \times 10^{-4}, 9$ : 4.49839x $10^{-3}, 10:-2.199010 \times 10^{-2}, 11$ : $2.57524 \times 10^{-2}, 12:-2.00574 \times 10^{-3}$

Fractional atomic coordinates and isotropic or equivalent isotropic displacement parameters $\left(\AA^{2}\right)$

\begin{tabular}{lllll}
\hline & $x$ & $y$ & $z$ & $U_{\text {iso }} * / U_{\text {eq }}$ \\
\hline $\mathrm{W} 1$ & $0.51352(13)$ & $0.80186(10)$ & $0.52310(10)$ & 0.01206 \\
$\mathrm{Na} 1$ & $0.3444(2)$ & $0.4957(2)$ & $0.58501(16)$ & 0.02213 \\
$\mathrm{Na} 2$ & $0.7422(2)$ & $0.54966(18)$ & $0.64745(14)$ & 0.02166 \\
$\mathrm{O} 1$ & $0.44940(14)$ & $0.82253(11)$ & $0.40144(8)$ & 0.01858 \\
$\mathrm{O} 2$ & $0.55647(14)$ & $0.63936(9)$ & $0.54135(9)$ & 0.01675 \\
$\mathrm{O} 3$ & $0.68666(14)$ & $0.89213(10)$ & $0.53870(10)$ & 0.02256
\end{tabular}


supporting information

$\begin{array}{lllll}\text { O4 } & 0.36916(14) & 0.85058(11) & 0.60895(9) & 0.01972 \\ \text { O5 } & 0.53794(17) & 0.40814(14) & 0.70116(12) & 0.02505 \\ \text { O6 } & 0.2276(2) & 0.64134(14) & 0.70148(11) & 0.02531 \\ \text { D51 } & 0.5576(2) & 0.32926(17) & 0.66767(12) & 0.03829 \\ \text { D52 } & 0.55912(18) & 0.39189(14) & 0.76800(13) & 0.03325 \\ \text { D61 } & 0.1229(2) & 0.64645(13) & 0.67384(10) & 0.03267 \\ \text { D62 } & 0.27774(17) & 0.71764(15) & 0.67874(12) & 0.03524\end{array}$

Atomic displacement parameters $\left(\AA^{2}\right)$

\begin{tabular}{lllllll}
\hline & $U^{11}$ & $U^{22}$ & $U^{33}$ & $U^{12}$ & $U^{13}$ & $U^{23}$ \\
\hline $\mathrm{W} 1$ & $0.0099(7)$ & $0.0064(6)$ & $0.0199(7)$ & $-0.0002(5)$ & $0.0009(6)$ & $0.0002(6)$ \\
$\mathrm{Na} 1$ & $0.0209(11)$ & $0.0167(9)$ & $0.0289(13$ & $0.0004(9)$ & $0.0028(9)$ & $0.0003(8)$ \\
$\mathrm{Na} 2$ & $0.0192(10)$ & $0.0183(11)$ & $0.0275(13)$ & $0.0001(8)$ & $-0.0006(8)$ & $0.0000(9)$ \\
O1 & $0.0170(6)$ & $0.0192(6)$ & $0.0195(7)$ & $0.0008(5)$ & $0.0010(6)$ & $0.0031(5)$ \\
O2 & $0.0176(6)$ & $0.0079(5)$ & $0.0248(7)$ & $0.0014(5)$ & $-0.0004(5)$ & $0.0035(5)$ \\
O3 & $0.0193(7)$ & $0.0190(6)$ & $0.0293(8)$ & $-0.0083(5)$ & $-0.0002(6)$ & $-0.0015(6)$ \\
O4 & $0.0201(6)$ & $0.0176(6)$ & $0.0214(7)$ & $0.0045(5)$ & $0.0052(6)$ & $0.0008(6)$ \\
O5 & $0.0305(9)$ & $0.0206(9)$ & $0.0241(8)$ & $-0.0027(7)$ & $-0.0031(7)$ & $-0.0023(7)$ \\
O6 & $0.0246(8)$ & $0.0247(8)$ & $0.0266(9)$ & $-0.0004(7)$ & $-0.0046(7)$ & $0.0061(7)$ \\
D51 & $0.0448(10)$ & $0.0304(9)$ & $0.0397(9)$ & $-0.0001(8)$ & $-0.0104(8)$ & $-0.0032(8)$ \\
D52 & $0.0415(9)$ & $0.0323(8)$ & $0.0259(8)$ & $-0.0027(7)$ & $-0.0001(8)$ & $0.0004(7)$ \\
D61 & $0.0259(9)$ & $0.0354(9)$ & $0.0367(9)$ & $-0.0011(7)$ & $-0.0030(7)$ & $0.0046(8)$ \\
D62 & $0.0347(9)$ & $0.0270(8)$ & $0.0440(11)$ & $-0.0059(7)$ & $-0.0029(7)$ & $0.0059(7)$ \\
& & & & & & \\
\hline
\end{tabular}

Geometric parameters $\left(\AA,{ }^{\circ}\right)$

\begin{tabular}{|c|c|c|c|}
\hline $\mathrm{W} 1-\mathrm{O} 1$ & $1.7849(19)$ & $\mathrm{Na} 2-\mathrm{O}^{\mathrm{v}}$ & $2.328(2)$ \\
\hline $\mathrm{W} 1-\mathrm{O} 2$ & $1.7779(15)$ & $\mathrm{Na} 2-\mathrm{O} 5$ & $2.409(3)$ \\
\hline $\mathrm{W} 1-\mathrm{O} 3$ & 1.7659 (17) & $\mathrm{Na} 2-\mathrm{O}^{\mathrm{vi}}$ & $2.311(2)$ \\
\hline $\mathrm{W} 1-\mathrm{O} 4$ & $1.7834(18)$ & O5-D51 & $0.9702(18)$ \\
\hline $\mathrm{Na} 1-\mathrm{O} 2$ & $2.433(2)$ & O5-D52 & $0.9591(16)$ \\
\hline $\mathrm{Na} 1-\mathrm{O} 2^{\mathrm{i}}$ & $2.412(3)$ & O6-D61 & $0.9684(16)$ \\
\hline $\mathrm{Na} 1-\mathrm{O} 3^{\mathrm{ii}}$ & $2.479(3)$ & O6-D62 & $0.9664(16)$ \\
\hline $\mathrm{Na} 1-\mathrm{O} 4^{\mathrm{iii}}$ & $2.399(2)$ & $\mathrm{D} 51-\mathrm{O} 1^{\mathrm{i}}$ & $1.873(2)$ \\
\hline $\mathrm{Na} 1-\mathrm{O} 5$ & $2.479(3)$ & D52-O4 ${ }^{\text {vii }}$ & $1.863(2)$ \\
\hline $\mathrm{Na} 1-\mathrm{O} 6$ & $2.443(3)$ & $\mathrm{D} 61-\mathrm{O} 1^{\mathrm{ii}}$ & $1.834(2)$ \\
\hline $\mathrm{Na} 2-\mathrm{O} 1^{\text {iv }}$ & $2.320(2)$ & $\mathrm{D} 62-\mathrm{O} 4$ & $1.876(2)$ \\
\hline $\mathrm{Na} 2-\mathrm{O} 2$ & $2.355(2)$ & & \\
\hline $\mathrm{O} 1-\mathrm{W} 1-\mathrm{O} 2$ & $108.40(9)$ & $\mathrm{O} 22^{\mathrm{i}-\mathrm{Na} 1-\mathrm{O} 6}$ & $174.55(12)$ \\
\hline $\mathrm{O} 1-\mathrm{W} 1-\mathrm{O} 3$ & $107.61(8)$ & $\mathrm{O} 4^{\mathrm{iii}}-\mathrm{Na} 1-\mathrm{O} 5$ & $99.82(9)$ \\
\hline $\mathrm{O} 1-\mathrm{W} 1-\mathrm{O} 4$ & $112.66(8)$ & $\mathrm{O} 4^{\mathrm{iii}}-\mathrm{Na} 1-\mathrm{O} 6$ & $90.40(8)$ \\
\hline $\mathrm{O} 2-\mathrm{W} 1-\mathrm{O} 3$ & $109.67(7)$ & $\mathrm{O} 5-\mathrm{Na} 1-\mathrm{O} 6$ & $94.37(10)$ \\
\hline $\mathrm{O} 2-\mathrm{W} 1-\mathrm{O} 4$ & $109.03(9)$ & $\mathrm{O} 1^{\mathrm{iv}}-\mathrm{Na} 2-\mathrm{O} 2$ & $95.10(8)$ \\
\hline $\mathrm{O} 3-\mathrm{W} 1-\mathrm{O} 4$ & $109.43(9)$ & $\mathrm{O}{ }^{\mathrm{iv}}-\mathrm{Na} 2-\mathrm{O}^{2}{ }^{\mathrm{v}}$ & $91.90(8)$ \\
\hline $\mathrm{O} 2-\mathrm{Na} 1-\mathrm{O} 2^{\mathrm{i}}$ & $86.16(7)$ & $\mathrm{O} 1^{\mathrm{iv}}-\mathrm{Na} 2-\mathrm{O} 5$ & $176.73(11)$ \\
\hline $\mathrm{O} 2-\mathrm{Na} 1-\mathrm{O} 3^{\mathrm{ii}}$ & $85.82(8)$ & $\mathrm{O}^{\mathrm{iv}}-\mathrm{Na} 2-\mathrm{O}^{\mathrm{vi}}$ & $93.43(9)$ \\
\hline
\end{tabular}




\begin{tabular}{|c|}
\hline ה \\
\hline $\mathrm{O}^{2}$ \\
\hline -O6 \\
\hline $\mathrm{O} 3^{\mathrm{ii}-\mathrm{N}}$ \\
\hline$-\mathrm{O} 4$ \\
\hline $\mathrm{O} 3^{\mathrm{ii}-\mathrm{Na} 1-\mathrm{O} 5}$ \\
\hline $\mathrm{O} 3^{\mathrm{ii}}-\mathrm{Na} 1-\mathrm{O} 6$ \\
\hline $\mathrm{O} 2^{\mathrm{i}}-\mathrm{Na} 1-\mathrm{O} 4^{\mathrm{ii}}$ \\
\hline $\mathrm{O} 2^{\mathrm{i}}-\mathrm{Na} 1-\mathrm{O} 5$ \\
\hline
\end{tabular}

$173.55(11)$

$84.60(8)$

$93.95(9)$

$88.32(8)$

$89.72(8)$

$170.42(10)$

$86.26(8)$

$89.05(8)$

$91.07(9)$
$\mathrm{O} 2-\mathrm{Na} 2-\mathrm{O}^{\mathrm{v}}$

$\mathrm{O} 2-\mathrm{Na} 2-\mathrm{O} 5$

$\mathrm{O} 2-\mathrm{Na} 2-\mathrm{O}^{\mathrm{vi}}$

$\mathrm{O} 3{ }^{\mathrm{v}}-\mathrm{Na} 2-\mathrm{O} 5$

$\mathrm{O} 3^{\mathrm{v}}-\mathrm{Na} 2-\mathrm{O}^{\mathrm{vi}}$

$\mathrm{O} 5-\mathrm{Na} 2-\mathrm{O}^{\mathrm{vi}}$

D51-O5-D52

D61-O6-D62
$93.36(8)$

$87.87(7)$

$111.09(9)$

$86.57(8)$

$154.35(11)$

$86.74(9)$

$105.96(19)$

$103.18(19)$

Symmetry codes: (i) $-x+1,-y+1,-z+1$; (ii) $x-1 / 2,-y+3 / 2,-z+1$; (iii) $-x+1 / 2, y-1 / 2, z$; (iv) $x+1 / 2,-y+3 / 2,-z+1$; (v) $-x+3 / 2, y-1 / 2, z$; (vi) $x+1 / 2, y$, $-z+3 / 2$; (vii) $-x+1, y-1 / 2,-z+3 / 2$. 